\title{
Evaluasi Pertambahan Bobot Badan, Konsumsi dan Konversi Ransum Ayam Kampung Super yang diberi Tepung Kunyit
}

\author{
Evaluation of Weight Gain, Consumption, Conversion Ration of Super Kampung \\ Chickens that given Turmeric flour
}

Sabrin Mohamad, *Fahria Datau, dan Nibras K. Laya,

Jurusan Peternakan, Fakultas Pertanian Universitas Negeri Gorontalo email:sabrinmohamad89@gmai.com

*Coresponding Author: email: fahria.datau@gmail.com

\begin{abstract}
The purpose of this study was to evaluate body weight gain (PBB), ration consumption and ration conversion of Kampung Super chickens fed with turmeric flour in their rations. Single factor analysis was used in this study. Turmeric flour was given in stages: $0 \%$ (control), $2 \%, 4 \%$, and $6 \%$. Based on the results of the evaluation for ration consumption, it showed that the provision of turmeric flour was not significantly different $(\mathrm{P}>0.05)$ on the ration of super native chicken consumption. The average feed consumption is 324.39-338.69 g / head. Evaluation of body weight gain, showed that giving turmeric flour had a significant effect $(\mathrm{P}<0.05)$ on body weight gain. The ration conversion evaluation showed that the use of turmeric flour had a significant effect $(P<0.05)$ on the ration conversion of Kampung Super chickens. The addition of 2-6\% turmeric flour to native chicken rations showed an increase in body weight, a decrease in ration conversion. The recommendation for using turmeric in the super native chicken ration is $4 \%$ of the total basal ration
\end{abstract}

Keywords: Body weight, ration consumption, ration conversion, Super Kampung Chicken, turmeric flour

\begin{abstract}
ABSTRAK
Tujuan penelitian ini adalah untuk mengevaluasi pertambahan bobot badan (PBB), konsumsi ransum dan konversi ransum ayam Kampung Super yang diberi tepung kunyit dalam ransumnya. Penelitian ini menggunakan metode single factor. Pemberian Tepung kunyit dilakukan secara bertahap yakni: P0: 0\% (kontrol), P1: 2\%, P2: 4\%, dan P5: 6\%. Analisis single factor digunakan dalam penelitian ini. Berdasarkan hasil evaluasi konsumsi ransum menunjukkan bahwa pemberian tepung kunyit tidak berbeda nyata $(\mathrm{P}>0,05)$ terhadap konsumsi ransum ayam kampung super. Rataan konsumsi pakan adalah 324,39-338,69 g/ekor. Evaluasi Pertambahan bobot badan menunjukkan bahwa pemberian tepung kunyit berpengaruh nyata $(\mathrm{P}<0,05)$ terhadap pertambahan bobot badan. Evaluasi konversi ransum menunjukkan bahwa penggunaan tepung kunyit dalam ransum berpengaruh nyata $(\mathrm{P}<0,05)$ terhadap konversi ransum ayam kampung Super. Penambahan tepung kunyit hingga $6 \%$ pada ransum ayam kampung menunjukkan peningkatan pertambahan bobot badan, penurunan konversi ransum, dan konsumsi ransum tetap. Rekomendasi penambahan kunyit pada ransum ayam kampung super adalah $4 \%$ dari total ransum basal
\end{abstract}

Kata Kunci :Ayam Kampung Super, Bobot badan, Konsumsi, konversi Kunyit

Cara Mengutip (APA Citation Style):

Mohamad, S., Datau, F., Laya, N, K., 2021. Evaluasi Pertambahan Bobot Badan, Konsumsi dan Konversi Ransum Ayam Kampung Super yang diberi Tepung Kunyit. Jambura Journal of Animal Science, 3(2), 113-119 


\section{PENDAHULUAN}

Pakan alternatif merupakan pakan tambahan atau subtitusi dalam ransum untuk ternak unggas, dengan tujuan penghematan. Bahan pakan yang difortifikasi untuk unggas memiliki nilai protein dan energi yang sangat baik sehingga dapat meningkatkan pertumbuhan, namun juga bahan pakan tersebut dapat merangsang aktivitas biologi, fisiologi dan imunitas dari ternak, salah satunya adalah kunyit.

Kunyit (Curcuma domestica val) dapat digunakan sebagai pakan tambahan, karena memiliki protein dan energy baik. Menurut Jarwati, (1998) Tepung kunyit memiliki kandungan air sebesar $14,57 \%$, protein sebesar $8,39 \%$, lemak sebesar $2,84 \%$, serat kasar sebesar $10,85 \%$, abu sebesar $8,32 \%$ dan karbohidrat sebesar $54,96 \%$. Selain itu Kunyit sebagai pemacu pertumbuhan atau imunomodulator dan anti bakteri pada ternak unggas, Karena menurut Abbas dan Lichtman, (2004) kunyit memiliki kandungan kurkuminoid sebesar 3-5 \%,minyak atsiri. Zat kurkumin ini menyebabkan adanya daya hambat anti bakteri, memacu pertumbuhan serta meningkatkan efisiensi pakan dengan mengurangi mikroorganisme pengganggu atau meningkatkan populasi mikroba yang menguntungkan, yang ada dalam saluran pencernaan ayam (Bintang dan Nataamijaya, 2005). Minyak atsiri dalam kunyit membantu pencernaan dengan merangsang sistem saraf sekresi untuk pengeluaran getah lambung yang mengandung enzim seperti pepsin, trypsin, lipase, amylase sehingga dapat meningkatkan metabolisme zat-zat makanan (Abbas dan Lichtman, 2004).

Peningkatan performa produksi pada unggas dilakukan Tini, W., dkk (2020) yakni pemberian ekstrak jamu menghasilkan konsumsi pakan, produksi telur, bobot telur, konversi pakan, dan skor warna kuning telur., sedangkan Pujianti, A., dkk, (2013) menyatakan pemberian tepung kunyit untuk ayam broiler meningkatkan daya cerna protein, tetapi tidak untuk bahan kering., dan menurunkan bobot badan dan konsumsi pakan ayam broiler serta berpengaruh pada nilai konversi pakan yang tinggi (Kristia N, D., dkk 2013). Menurut Nur, K., dan Sari, A., (2020) penambahan kunyit ke dalam pakan ayam broiler mampu membantu meningkatkan kualitas karkas dengan penyerapan nutrisi yang lebih optimal pada daging. Pemberian tepung kunyit pada ternak itik juga tidak berpengaruh nyata terhadap konsumsi, pertambahan bobot badan dan konversi pakan (Marra J. B., 2016).

Informasi penggunaan kunyit untuk ayam hasil silangan masih sangat kurang dan sangat dibutuhkan guna mengungkapkan kemampuan produktifitas dari ayam kampung super dalam memanfaatkan tepung kunyit,. Hal ini disebabkan ayam kampung super ini berbeda dengan ayam kampung, ayam broiler atau ayam ras lainnya yang memiliki kestabilan genetic, sehingga walaupun diberi perlakuan kunyit, tidak akan mempengaruhi performans dari ayam tersebut., sedangkan ayam kampung super memiliki tingkat keragaman yang tinggi dan juga kestabilan genetic belum maksimal (Dako, dkk, 2019; Dako, et al, 2020). Ayam kampung super memiliki kelebihan waktu panen di umur 2 bulan, dan saat bobot tubuh ayam minimal 0,850.75 kg/ekor (Sigaha, F., dkk, 2019). Kecepatan tumbuh ayam ini sangat baik (Sofjan, 2012) dibanding ayam kampung, karena merupakan penggabungan genetic dari strain yang berbeda (ayam kampung dan ayam leghorn betina) (Dako, S, 2018; Saleh , dkk 2020).

Menurut Datau F, dkk (2020) pemberian kunyit yang dicampur dengan ransum dapat memperbaiki karateristik feces ayam kampung super sebagai upaya meminimalisasi amoniak dalam kandang, sedangkan Kristia N, D., dkk (2013) aditif kunyit meningkatkan rataan bobot relatif proventrikulus tetapi tidak meningkatkan rataan bobot relatif gizzard, hati, duodenum, jejunum, ileum dan sekum 
dari ayam broiler. Tujuan Penelitian ini untuk mengetahui kemampuan Produktivitasi yang kampung super terhadap pemberian pakan yang mengandung kunyit

\section{METODOLOGI PENELITIAN}

Penelitian telah dilaksanakan di bulan Mei-September 2020 di Lab. Produksi ternak Unggas, Jurusan Peternakan Fakultas Pertanian, Universitas Negeri Gorontalo. Sebanyak 20 unit kandang batrei, ukuran $64 \times 32 \mathrm{~cm}$, yang diisi ayam kampung super sebanyak 120 ekor.

Pembuatan tepung kunyit mengikuti teknik yang digunakan Datau F, dkk. (2020); Dungio, dkk, (2021),

Tabel 1. Komposisi dan kandungan pakan ayam kampung super

\begin{tabular}{|c|c|c|c|c|}
\hline Bahan Pakan (\%) & P0 & P1 & $\mathbf{P 2}$ & P3 \\
\hline Jagung Kuning & 40 & 38 & 36 & 34 \\
\hline Tepung Kunyit & 0 & 2 & 4 & 6 \\
\hline Konsentrat & 38 & 38 & 38 & 38 \\
\hline Bekatul & 20 & 20 & 20 & 20 \\
\hline Premix & 2 & 2 & 2 & 2 \\
\hline Total & 100 & 100 & 100 & 100 \\
\hline \multicolumn{5}{|l|}{ KandunganNutrisi } \\
\hline BahanKering (\%) & 87,07 & 87,22 & 87,36 & 87,50 \\
\hline $\mathrm{ME}(\mathrm{Kkal} / \mathrm{kg})$ & 3123.62 & 3130.85 & 3138.09 & 3145.33 \\
\hline Protein Kasar (\%) & 21,52 & 21,62 & 21,72 & 21,82 \\
\hline SeratKasar $(\%)$ & 4,39 & 4,84 & 5,28 & 5,73 \\
\hline Lemak Kasar (\%) & 6,87 & 6,73 & 6,59 & 6,45 \\
\hline $\mathrm{Ca}(\%)$ & 0,82 & 0,83 & 0,84 & 0,85 \\
\hline $\mathrm{P}(\%)$ & 0,68 & 0,67 & 0,67 & 0,67 \\
\hline \multicolumn{5}{|c|}{ Tabel 2. Kandungan Nutrisi Tepung Kunyit } \\
\hline Kandungan & & & Jumlah & \\
\hline Protein $(\%)$ & & & 9,68 & \\
\hline Serat Kasar (\%) & & & 2,93 & \\
\hline Lemak $(\%)$ & & & 2,47 & \\
\hline Abu (\%) & & & 4,07 & \\
\hline $\operatorname{air}(\%)$ & & & 14,63 & \\
\hline $\operatorname{BETN}(\%)$ & & & 80,85 & \\
\hline Energi (\%) & & & 5475 & \\
\hline
\end{tabular}

Proses Pembersihan. Kunyit dicuci terlebih dahulu hingga bersih, dikikis kulit luarnya yang masih tertinggal akar dan tanah. Pemanasan kering.langkah selanjutnya kunyit diiris tipis-tipis. Irisan kunyit tersebut kemudian diangin-anginkan selama 2 hari dan dioven dengan suhu $\pm 50^{\circ} \mathrm{C}$ selama 1 hari. Penghalusan. Kunyit yang telah melalui proses pemanasan kering dilakukan penghalusan dengan cara digiling halus.

Penelitian ini menggunakan Rancangan Acak Lengkap (RAL) dengan 4 perlakuan dan 5 ulangan sehingga terdapat 20 unit percobaan

Ket: Datau F, dkk (2020)

Setiap percobaan terdiri dari 6 ekor

ayam. Adapun perlakuan yang akan dilakukan yaitu : $\mathrm{P} 0=$ Ransum basal tanpa tepung kunyit., P1 = Ransum basal + Tepung kunyit 2\% dari total ransum., P2 = Ransum basal + Tepung kunyit 4\% dari total ransum yang di gunakan., $\mathrm{P3}=$ Ransum basal + Tepung kunyit 6\% dari total ransum yang digunakan. Model matematika dari rancangan single factor mengikuti saran Syahruddin, S., dkk,(2020) adalah sebagai berikut:

Keterangan:

$$
Y_{i j}=\mu+t_{i}+e_{i j}
$$

Yij $=$ Total rataan pengamatan dari perlakuan pakan ke-i dan ulangan ke-j

$\mu=$ Nilai tengah umum

ti = Pengaruh Pakan yang diberikan ke-i

eij = Pengaruh galat percobaan dari pakan yabg diberikan ke-i dan ulangan ke-j

i = Jumlah perlakuan pakan 1,2,3,4

$\mathrm{j} \quad=$ jumlah ulangan pada perlakuan pakan ke-1,2,3,4,5 
Data dianalisa menggunakan analisis sidik ragam (ANOVA), mengikuti saran Ali, dkk, (2019).

\section{HASIL DAN PEMBAHASAN}

\section{Konsumsi Ransum}

Ransum merupakan bagian terpenting dalam pertumbuhan dan perkembangan ayam kampung super.

Ransum yang dikonsumsi oleh ternak ayam, diproses sehingga dapat diserap oleh tubuh. Hasil pengamatan pemberian pakan mengandung kunyit selama penelitian disajikan pada tabel 3 .

Hasil analisis menunjukkan bahwa pemberian penambahan tepung kunyit dalam ransum ayam kampung super ditiap perlakuan tidak berbeda nyata $(\mathrm{P}>0,05)$ terhadap konsumsi pakan ayam kampung super.

Tabel 3. Rataan konsumsi ransum, pertambahan bobot badan, konversi ransum Bobot potong, Bobot karkas, dan organ.

\begin{tabular}{lrrrr}
\hline \multicolumn{1}{c}{ Variabel } & \multicolumn{4}{c}{ Perlakuan } \\
\cline { 2 - 5 } & \multicolumn{1}{c}{ P0 } & P1 & P2 & \multicolumn{1}{c}{ P3 } \\
\hline Konsumsi Pakan & $338.69^{\mathrm{ns}}$ & $330.29^{\mathrm{ns}}$ & $332.06^{\mathrm{ns}}$ & $324.39^{\mathrm{ns}}$ \\
Pertambahan bobot badan & $106.93^{\mathrm{a}}$ & $101.51^{\mathrm{ab}}$ & $110.96^{\mathrm{ab}}$ & $98.17^{\mathrm{b}}$ \\
Konversi ransum & $3.16^{\mathrm{a}}$ & $3.26^{\mathrm{ab}}$ & $2.99^{\mathrm{ab}}$ & $3.309^{\mathrm{b}}$ \\
\hline
\end{tabular}

Keterangan : Superscrip yang berbeda menggabarkan perbedaan yang nyata $(\mathrm{P}<0.05)$

P0 = Ransum basal tanpa tepung kunyit

$\mathrm{P} 1=$ Ransum basal + Tepung kunyit $2 \%$ dari total ransum yang di gunakan

$\mathrm{P} 2=$ Ransum basal + Tepung kunyit $4 \%$ dari total ransum yang di gunakan

P3 $=$ Ransum basal + Tepung kunyit $6 \%$ dari total ransum yang digunakan

Jumlah ransum yang dikonsumsi secara statistic dianggap sama disemua perlakuan tidak berbeda nyata, hal ini berarti penambahan tepung kunyit dalam ransum di level $2 \%, 4 \%, 6 \%$ adalah sama dengan level $0 \%$ adalah kesemuanya tidak memberikan pengaruh terhadap konsumsi. Terutama protein dan energy (Tabel 1) dalam ransum adalah sama, selain itu bentuk pakan yang diberikan selama penelitian adalah berbentuk halus. Faktor dominan yang mempengaruh banyak dan sedikitnya jumlah konsumsi pakan adalah kandungan energy dan protein pakan, dan suhu lingkungan yang mempengaruhi ternak (North dan Bell, 1990). Selanjutnya Tillman et al., (1989) menyatakan bahwa konsumsi ransum dipengaruhi oleh bentuk dan fisik pakan, dan komposisi kimia ransum, frekuensi pemberian dan anti nutrisi dalam ransum.Penyebab konsumsi yang sama disebabkan ayam kampung super yang digunakan dalam penelitian ini memiliki umur yang sama, keturunan, dan bobot tubuh yang relative sama saat diberi perlakuan, sehingga menyebabkan jumlah konsumsi tidak berbeda.
Pemberian pakan yang berbentuk halus selama penelitian menyebabkan pengambilan pakan tidak merata, berakibat ayam lebih banyak minum.Peryataan ini didukung Murtidjo (2006) menyatakan bahwa pakan yang berbentuk tepung (mash) cepat diserap oleh usus tetapi sulit dimakan karena berdebu (berbentuk tepung) sehingga ayam cenderung tidak bergairah untuk memakannya. Samarasinghe et.al. (2003) melaporkan tidak adanya pengaruh yang signifikan pada konsumsi ayam broiler yang diberi tepung kunyit hingga $3 \mathrm{~g} / \mathrm{kg}$ pada pakan. Jihadulhaq Bin Marra (2016) juga menyatakan bahwa penambahan tepung kunyit hingga $2 \%$ pada itik tidak memberikan pengaruh nyata terhadap konsumsi pakan.

Pertambahan Bobot Badan

Pertambahan bobot badan (PBB) ayam kampung super merupakan pertambahan nilai selesih bobot badan, berbanding lama waktu pemeliharan. Pertambahan bobobt badan selama enam minggu menunjukan pemberian tepung kunyit berpengaruh nyata $(\mathrm{P}<0.05)$ 
terhadap pertambahan bobot badan. Berdasarkan hasil uji lanjut BNJ menggambarkan perbedaan terjadi diperlakuan P2 yakni pada level penambahan tepung kunyit $4 \%$ dalam ransum. Perbedaan bobot badan disebabkan adanya kandungan kurkumin yang membantu proses penyerapan nutrisi terutama metabolismeprotein dan energi untuk pembentukan daging. Kurkumin yang membantu proses cerna makanan didalam lambung, dan imunomodulator (pemacu pertumbuhan). Menurut Pratikno, (2010); Peningkatan berat badan ayam ini menggambarkan adanya pemanfaatan pakan menjadi efisien melalui metabolisme yang dibantu oleh ekstrak kunyit yang diberikan melalui pakan sehingga menghasilkan bobot badan yang lebih besar. Yuniusta, dkk, (2007) Kandungan kurkumin dan minyak atsiri mengkatifasi proses metabolisme enzimatis pada tubuh ayam. Kurkumin dan minyak atsiri dapat mempercepat pengosongan lambung, dengan hal demikian akan timbul rasa lapar dan timbul nafsu makan (Wijayakusuma, 2003; Salau, 2015; Dahrut, 2017).

\section{Konversi Ransum}

Konversi pakan selama penelitian diukur berdasarkan jumlah konsumsi pakan berbanding bobot badan selama penelitian. Hasil analisis menunjukan bahwa penggunaan tepung kunyit dalam ransum ayam kampung super memberikan pengaruh nyata $(\mathrm{P}<0,05)$ terhadap konversi pakan.,

Hasil uji BNJ menunjukan perbedaan terjadi pada perlakuan P2 (4\% kunyit) memiliki nilai konversi ransum lebih rendah dibanding kelompok control

\section{DAFTAR PUSTAKA}

Abbas AK, Lichtman AH. (2004). Basic Immunology: Functions and dissorders of the immune system. Ed. Ke-2. Philadelphia (US): Saunders. sedangkan perlakuan lainnya nilainya hampir sama dengan control. Konversi ransum yang berbeda (Tabel 1) disebabkan oleh perbedaan laju pertambahan berat badan di masing-masing kelompok ayam, ini juga menggambarkan kemampuan ayam kampung super dalam manfaatkan kurkumin dalam membantu proses metabolisme protein dan energy berbeda atau beragam. Kemampuan ini merupakan sifat genetic karena menurut Masili dkk (2018) Ayam hasil silangan memiliki kemampuan produksi dan reproduksi yang beragam., karena kestabilan genetic belum maksimal (beragam) (Dako, et al, 2020). Hal ini dapat menyebabkan perbedaan konversi pakan perlakuan. Hal ini sesuai dengan penelitian yang telah dilakukan oleh Setyaningrum $d k k$, (2014) menyatakan bahwa faktor yang mempengaruhi konversi ransum agar efisien adalah energi ransum, kualitas pakan, dan kecernaan pakan .

\section{KESIMPULAN}

Penambahan tepung kunyit hingga $4 \%$ didalam ransum ayam kampung super mensitimulus kenaikan pertambahan bobot badan, mampu menurunkan nilai konversi ransum, dan konsumsi ransum tetap, rekomendasi penambahan kunyit didalam ransum ayam kampung super adalah 4-6\% dari total ransum basal.

\section{UCAPAN TERIMA KASIH}

Disampaikan terima kasih kepada Jurusan Peternakan, Fukultas Pertanian, Universitas Negeri Gorontalo atas bantuan dalam pendanaan penelitian ini, melalui dana PNBP FAPERTA UNG dalam skin penelitian Kolaborati

Ali, L., Gubali, S. I., \& Saleh, E. J. (2019).Penampilan Produksi Telur Burung Puyuh Pada Tingkat Kepadatan Kandang Yang Berbeda.Jambura Journal of Animal Science, 2(1), 8-12.

Bintang, I.A.K dan A.G. Nataamijaya. (2005). Pengaruh penambahan 
tepung kunyit (Curcuma domestica Val.) dalam ransum broiler.http:/ / peternakan.litbang.de ptan.go.id/fullteks/ semnas/pro05-103.pdf. (April 2020).

Dunggio, A., Datau, F., Dako, S., \& Handayani, S. Evaluasi Karkas Ayam Kampung Super Yang Diberi Tepung Kunyit (Curcuma domestica val). AgriSains, 22(1), 11-16.

Dahrut, A. (2017). pengunaan ekstrak temulawak (curcuma xanthorrhiza roxb) dalam air minum terhadap produksi dan kualitas telur burung puyuh (coturnix-coturnix japonica) fase layer. Skripsi, 1(621410088).

Dako, S. (2019). Crossbreding Between Native Chiken And Leghorn Chiken Strain Isa Brown. Jurnal Peternakan, 16(1), 1-9.

Dako, S., Ilham, F., Laya, N. K., \& Yusuf, M. F. (2019). Manajemen pembibitan Ternak. Buku Ajar, Publisher Arthasamudra ISBN, 978-623.

Dako, S., Ilham, F., Laya, N. K., \& Yusuf, F. M. (2020). Nheritance of external genetic characteristics in chicken through triple crossing model. International Journal of Advanced Science and Technology, 29(9 Special Issue).http://sersc.org/journals/ind ex.php/IJAST/article/view/13134

Datau, F., \& Dako, S. (2020). Karateristik Feses Ayam Kampung Super Yang Diberi Kunyit. Jambura Journal of Animal Science, 3(1), 31-37.

Dunggio, A., Datau, F., Dako, S., dan Handayani, S. (2021) Evaluasi Karkas Ayam Kampung Super Yang Diberi Tepung Kunyit (Curcuma domestica val) Jurnal AgriSains, 22 (1), 11-16

Publisher: Animal husbandry department, Gorontalo State University http://ejurnal.ung.ac.id/index.php/jjas/issue/archive
Jarwati. (1998). Evaluasi penambahan temulawak (Curcuma xantorhriza, roxb) atau kunyit (Curcuma domestika, val) pada pakan terhadap daging domba ekor tipis. Skripsi. Jurusan Teknologi Industri Pertanian Fakultas Pertanian Institut Pertanian Bogor, Bogor.

Jihadulhaq Bin Marra. 2016. Pengaruh Penggunaan Tepung Kunyit (Curcuma domestica val) Terhadap Performa Itik Lokal (Anas sp.). Program Studi Peternakan. Fakultas Peternakan. Universitas Hasanuddin. Makassar

Kristia N, D., Warsito, S. H., Utomo, R. B., \& Lamid, M. (2013). Pengaruh Pemberian Tepung Kunyit (Curcuma domestica) Dan Tepung Daun Seligi (Phyllanthus buxifolius) Dalam Pakan Terhadap Performans Ayam Broiler Jantan. Jurnal Agro Veteriner, 2(1), 43-53.

Masili, S., Dako, S., Ilham, F., \& Gubali, I. S. (2018). Heritabilitas Bobot Telur, Bobot Tetas Dan Bobot Badan Ayam Hasil Persilangan Umur 1 Minggu (DOC). Jambura Journal of Animal Science, 1(1), 1-5.

North M. O. dan Bell D. D. 1990. Commercial Chicken Production Manual. Ed ke-4. Wesport, Connecticut (US): Avi Publishing Company Inc

Pratikno, H (2010) Pengaruh Ekstrak Kunyit (Curcuma DomesticaVahl) Terhadap Bobot Badan Ayam Broiler (Gallus Sp) Buletin Anatomi dan FisiologiVol. XVIII, No. 2, Oktober 20103.

Pujianti, A., Jaelani, A., \& Widaningsih, N. (2013). Penambahan Tepung Kunyit (Curcuma domestica) Dalam 
ransum Terhadap Daya Cerna Protein dan Bahan Kering Pada Ayam Pedaging. Ziraa'ah Majalah Ilmiah Pertanian, 36(1), 49-59.

Saleh, U. (2020). Keseimbangan Genetik Eksternal pada Ayam Hasil Silangan. Jambura Journal of Animal Science, 2(2), 76-89.

Salau, N. (2015). Pemberian Ekstrak Temulawak dalam air minum terhadap pertambahan bobot badan, konsumsi dan konversi pakan burung puyuh. Skripsi, 1(621410048).

Samarasinghe K., C. Wenk., K. F. S. T. Silva and J.M.D.M. Gunasekera . 2003. Turmeric (Curcuma longa), root powder and manano ligo Sacharides as alternatif to antibiotic in broiler chicken diets. Asian-Aust. J. Anim. Sci. 16: 1495-1500.
Sigaha, F., Saleh, E. J., \& Zainudin, S. (2019). Evaluasi Persentase Karkas Ayam Kampung Super Dengan Pemberian Jerami Jagung Fermentasi.Jambura Journal of Animal Science, 2(1), 1-7.

Sofjan I. 2012. Ayam Kampung Unggul Balintnak. Badan Penelitian Dan Pengembangan Pertanian. Jakarta

Syahruddin, S., Nahrowi, N., \& Yatno, Y. (2020). Kemampuan Polisakarida Mannan Sebagai Oral Adjuvan Vaksin Avian Influenza pada Ayam Broiler.Jambura Journal of Animal Science, 2(2), 90-101.

Tillman, A.D., H. Hari., R. Soedomo., P. Soeharto dan L. Soekanto. 1989. Ilmu Makanan Ternak Dasar.Gajah Mada University Press. Yogyakarta 